candidate of philological sciences, associate professor

Tver branch of FSBEI of HE “The Russian Presidential Academy of National Economy and Public Administration"

Tver, Tver Region

DOI $10.31483 / r-98695$

\title{
AMBIGUITY OF FUTURE IN THE PAST IN THE MODERN ENGLISH LANGUAGE
}

Abstract: the article raises the question of ambiguity of Future in the Past in expressing the future tense in the modern English language. The author of the article analyzes should/would + infinitive, its grammatical status and the expressed lexical meaning. The article notes that ambiguity of Future in the Past is mainly due to the homonymy of should/would + infinitive forms with the forms of the subjunctive mood. However, Future in the Past is a part of the verb system of tenses in the modern English language and it expresses assumption, intention or obligation to perform a future action from the past position.

Keywords: Future in the Past, should/would + infinitive, subjunctive mood, tense, modality, the English language.

\section{Селезнева Ольга Николаевна} канд. филол. наук, доцент

Тверской филиал ФГБОУ ВО «Российская академия народного хозяйства и государственной службы при Президенте Российской Федерации»

г. Тверь, Тверская область

\section{НЕОДНОЗНАЧНОСТЬ FUTURE IN THE PAST \\ В СОВРЕМЕННОМ АНГЛИЙСКОМ ЯЗЫКЕ}

Аннотация: в статье поднимается вопрос о неоднозначности Future in the Past в выражении будущеего времени в современном английском языке. Автор статьи анализирует форму should/would + infinitive, ее грамматический статус 
и выражаемое лексическое значение. В статье отмечается, что неоднозначность Future in the Past обусловлена главным образом омонимичностью should/would + infinitive формам сослагательного наклонения. Тем не менее Future in the Past является частью глагольной системы времен современного английского языка и выражает предположение, намерение или обязательство совершения будущуего действия с позищчи прошедщего.

Ключевые слова: Future in the Past, should/would + infinitive, cocлагательное наклонение, время, модальность, английский язык.

One of the most controversial forms when discussing the meaning of the future tense expression is Future in the Past, in other words, should/would + infinitive. The combination should/would + infinitive differs from other ways of expressing the future, firstly, because there is a natural doubt about its attribution to the category of time. For example, a famous Russian linguist A.I. Smirnitskiy considers Future in the Past to be a part of the conditional mood but not the tense and gives the following reasons. To begin with, Future in the Past is mostly used in indirect speech, and the time of the statement's utterance belongs to the sphere of the past, so it is impossible to determine to which time interval the action itself belongs to. In addition, it remains unknown whether the action was performed at all [7, p. 356]. Secondly, in relation to the present time, the action which is expressed by should/would + infinitive appears as unreal, which brings the construction closer to the conditional mood, the main meaning of which is "conditioned unreality" [7, p. 351]. It is called conditional because it shows the invalidity of any other circumstances or conditions. A.I. Smirnitskiy also believes that with the outward coincidence of forms, the meanings of Future in the Past and the conditional mood are not identical, but they do not contradict each other: «We can say with good reason that Future in the Past does not stand out as a special form of time, but it is included in the conditional mood as a special case of the use of the conditional mood, the possibility of which is determined by its general meaning» [7, p. 357].

The homonymy of the Future in the Past form to the subjunctive I form is also noted in the works of such researches as L.S. Barkhudarov, D. Ya. Shtelling, who 
attribute should/would + infinitive to the forms used in additional clauses in a dependent syntactic position, if the predicate verb in the main sentence is in the past tense. At the same time, the same as in the case of the subjunctive mood, they can be both imperfect ("He said he would come") and perfect ones ("I said I should have come by then") [1]. It is noted that English is characterized by the use of Future in the Past in additional clauses after verbs in the past tense with the meaning of speech and mental activity: to say, to tell, to announce, to think, to know, to believe, to expect and others. This phenomenon is called by Barkhudarov as "time alignment" [1]. However, there are many cases where "tenses are not reconciled", and even if the predicate verb in the main clause is in the past tense, the verb in the subordinate clause is put in the future tense. This happens with an objective statement of some fact related to the future, which is common primarily for the colloquial style and language of newspaper reports. In such cases, the modal meaning of the Future form comes to the fore [1].

According to R. Quirk, the meaning of should/would + infinitive is the designation of a future action, viewed from the perspective of the past. As an additional meaning of should/would + infinitive, the researcher indicates a regularly repeated action in the past. The linguist considers should /would + infinitive both as a means of the category of tense and as a means of the mood category [6, p. 52-55].

D. Biber, S. Johansson, G. Leech, S. Conrad, E. Finegan (Longman Grammar, 1999) consider should/would in the combination should/would + infinitive as the corresponding modal verbs shall/will in the past form, with positions of the past tense in future actions' designation: "I knew that I would gain weight" [5, p. 485]. The researchers also note that the action expressed by should/would can be predictive ("She would feel much better if she went out", "Cheap money would have the same effect by increasing private investment"), denote a personal expression of will ("I would just read the book as well"' [6, p. 495-496].

G.A. Weikhman clarifies that, despite the fact that the verb would is the past form of the verb will, the latter cannot be replaced by would in the meaning of desire due to a possible distortion of the meaning (would as a designation of a repetitive action in the past). In this case, synonymous verbs are usually used, such as wanted, intended 
[8, p. 33]. Similarly, it is not always possible to replace shall with should: "Shall we dance?" is interpreted as an invitation to dance. "Should we dance?" is the question of whether it is necessary to dance [9, p. 157-160]. This position shows that in modern English there is a tendency to perceive should/would not as just the past form of the verbs shall/will, but as independent verbs.

Thus, based on the works of researchers, we can distinguish the following semes of Future in the Past meanings: intention or obligation to perform an action, forecast, expression of indirect or improper direct speech, subjective modality.

Let us move to some examples in order to practically consider the usage of Future in the Past in the modern English language.

Example 1. The graphic designer mocked up fake bank statements in 1995 at the request of Panorama interviewer Martin Bashir. But he did not know what they would be used for until after the broadcast [2].

The form would be used expresses an assumption of the future action seen from the past. Here the verb would can be characterized not as a modal verb, but as an auxiliary one.

Example 2. He said that shortly after the couple announced they would step back from royal duties, someone who was "friends with a lot of the editors" had warned him about their confrontational stance with the press: "Please don't do this with the media, they will destroy your life" [3].

Example 3. Thousands of people fled their homes in the Democratic Republic of Congo during the night after a large volcano erupted. As the sky turned red and rivers of lava streamed from Mount Nyiragongo, there were concerns that its past deadly tragedies would be repeated [4].

The form would be repeated expresses an assumption of the future action seen from the past. Here the verb would can be characterized not as a modal verb, but as an auxiliary one.

The form would stay back expresses an intention or obligation of the future action seen from the past. Here the verb would can be characterized not as a modal verb, but as an auxiliary one. 
To sum up, despite the problem of ambiguity, concerning Future in the Past in the modern English language because of homonymy of should/would + infinitive with the forms of subjunctive mood, Future in the Past, namely, should/would + infinitive is a part of the verb system of tenses, the verbs should and would act out more as auxiliary verbs than as modal ones, the construction expresses assumption, intention or obligation to perform a future action from the past position.

\section{References}

1. Barkhudarov L. Shtelling, D. English Grammar. M., 1960. 423 p. URL: https://obuchalka.org/2018010298314/grammatika-angliiskogo-yazika-barhudarov-ls-shteling-d-a-1960.html

2. BBC News. Lee Joseph. Diana interview: Whistleblower wants apology from BBC bosses: URL: https://www.bbc.com/news/uk-57199164 (dated 21.05.2021).

3. BBC News. Meghan and Harry interview: Tabloid racism 'large part' of why we left UK, says duke. URL: https://www.bbc.com/news/uk-56324215 (dated 08.05.2021).

4. BBC News. Mount Nyiragongo: DR Congo residents flee as volcano erupts. URL: https://www.bbc.com/news/world-africa-57215690 (dated 23.05.2021).

5. Longman Grammar of Spoken and Written English / Biber D., Johansson S., Leech G., Conrad S., Finegan E. London: First Edition, 1999. 1204 p.

6. Quirk R., Greenbaum S., Leech G., Svartvik J. A University Grammar of English. M., 1982. 391 p.

7. Smirnitskiy A.I. Morphology of the English language. M, 1957. 500 p.

8. Weikhman, G. New in the English Grammar. M., 1990. 127p.

9. Weikhman, G. New in the modern English Grammar: manual for universities. M., 2002. 554 p. 